\title{
プレキャストセグメントエ法における 諸方策と品質の実例
}

\author{
白石暢明 1 ・竹林稔雄 ${ }^{2}$ \\ (株) 熊谷組 海外本部夕イ営業所（タイ国バンコク市） \\ 2正会員 (株) 熊谷組 技術本部土木技術部（干162 東京都新宿区津久戸町 2-1）
}

\begin{abstract}
バンコク第二高速道路工事では, 高架橋の標準構造形式として外ヶーブル・ドライジョイントによるプレキャ ストセグメント桁, さらにその架設工法としてスパンバイスパン工法が採用され，大規模・急速施工に大きく貢 献した。本報告では，計画・設計・施工の各段階で取られた単純化，標準化などの方策，管理状況およびその結 果として得られた工程・品質などに関し, 種々の工事関連データを提示することにより概要を述べる.
\end{abstract}

Key Words : precast segmental bridge, external tendons, dry joint, span-by-span erection, simple beam

\section{1. まえがき}

1990 年 2 月に着工されたバンコク第二高速道路工事 （第一期工事区, 全長約 $20 \mathrm{~km}$ ) は 1993 年 7 月に完成, 同 年 9 月に開通した（写真一1）。本高速道路は大部分が高 架橋であり，その標準構造形式として採用されたプレ キャストセグメント PC 箱桁橋の使用規模は, 単一のプ ロジェクトにおいては現時点で世界最大となる.

本工事では, 規模のメリットを最大限に活かすため, 計画・設計・施工の各段階において様々な方策を施し た。 それらは, プレキャストセグメント，外ケーブル， ドライジョイントなどに代表される構造の単純化・標準 化, ショートライン・マッチキャスティング工法, スパ ンバイスパン工法に見られる施工の機械化，あるいはプ ロジェクトマネージャー組織やキャスティングヤード設 備のような集中化・一貫化といった形で具現化された。

本文では，プレキャストセグメント工法に関する工事 データを整理することにより, 上述のような種々の方 策, 管理状況およびその結果として得られた工程, 品質, 問題などの概要を示す.

\section{2. 全体概要 ${ }^{(1)-4)}$}

\section{(1) 工事概要}

主要工事数量および全体工程を表一 1,2 に示す.

\section{(2) 高架橋構造概要}

高架橋の一般概要を表一 3 に示す．また，プレキャス

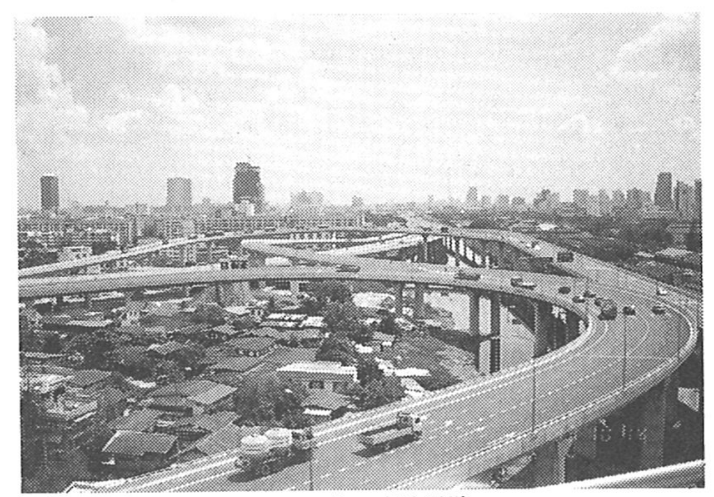

写真一1 バンコク第二高速道路

(インターチェンジ開通後風景)

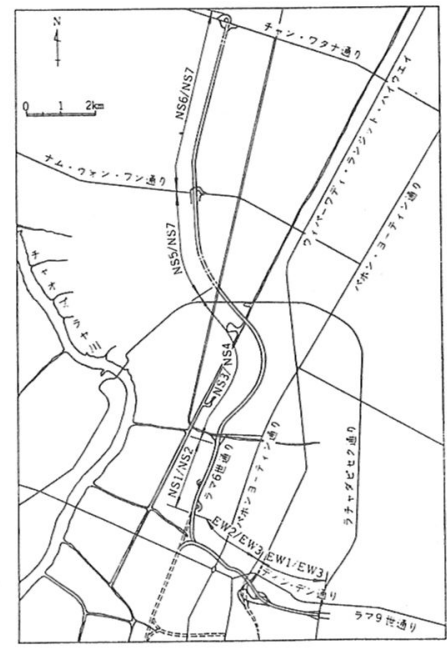

図一1 第一期工事区の工区構成 
表一1 主要工事数量（第 1 期工事区）

\begin{tabular}{|c|c|c|c|c|c|c|c|}
\hline \multirow[t]{2}{*}{ I区 * } & 上部工 & EW3 & NS2 & NS4 & NS7 & \multirow{2}{*}{ 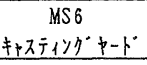 } & \multirow[b]{2}{*}{ 計 } \\
\hline & 下部工 & EW1, EW2 & NS1 & NS3 & NS5, NS6 & & \\
\hline \multicolumn{2}{|c|}{ 本線延長 $(\mathrm{km})$} & 5.1 & 2.2 & 5.0 & 7.4 & - & 19.7 \\
\hline \multicolumn{2}{|c|}{ 全舗装面積 $\left(\mathrm{m}^{2}\right)$} & 338000 & 177000 & 209000 & 274000 & - & 998000 \\
\hline \multicolumn{2}{|c|}{ 高架橋面積 $\left(\mathrm{m}^{2}\right)$} & 217000 & 89000 & 151000 & 131000 & - & $588 \quad 000$ \\
\hline \multicolumn{2}{|l|}{ 料金所 } & 4 & 3 & 2 & 3 & - & 12 \\
\hline \multicolumn{2}{|c|}{ コソクリ $-卜\left(\mathrm{~m}^{3}\right)$} & 165000 & 121000 & 99000 & 109000 & 285000 & 779000 \\
\hline \multicolumn{2}{|l|}{ 鉄筋 $(t)$} & 23000 & 19000 & 13000 & 15000 & $44 \quad 000$ & 114000 \\
\hline \multicolumn{2}{|c|}{ 자ラット $(t)$} & 5000 & 3000 & 3000 & 3000 & 3000 & 17000 \\
\hline \multicolumn{2}{|c|}{ 場所打亏杭 (m) } & 69000 & $38 \quad 000$ & 45000 & $46 \quad 000$ & - & $198 \quad 000$ \\
\hline \multicolumn{2}{|c|}{ 打込み杭 (m) } & 125000 & 35000 & 39000 & $46 \quad 000$ & - & $245 \quad 000$ \\
\hline \multicolumn{2}{|c|}{ U析・I 析径間数 } & 55 & 139 & 0 & 2 & - & 198 \\
\hline \multicolumn{2}{|c|}{ U析. I 析本数 } & 226 & 718 & 0 & 6 & - & 950 \\
\hline \multicolumn{2}{|c|}{ 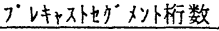 } & 511 & 0 & 293 & 327 & - & 1131 \\
\hline \multicolumn{2}{|c|}{$フ^{\circ}$ レャャストセグメント個数 } & $6 \quad 392$ & 0 & 3802 & 4280 & $14474 * *$ & $14 \quad 474 * *$ \\
\hline
\end{tabular}

*:第一期工事区工区名（EW1～EW3,NS1～NS7）に関しては図-1を参照のこと。

**: 載荷試験用に製作した貔メン14個を加えると、製作総数は14488個（再製作分25個は除く）となる。

表一2 実施工程表（プレキャストセグメント部分のみ）

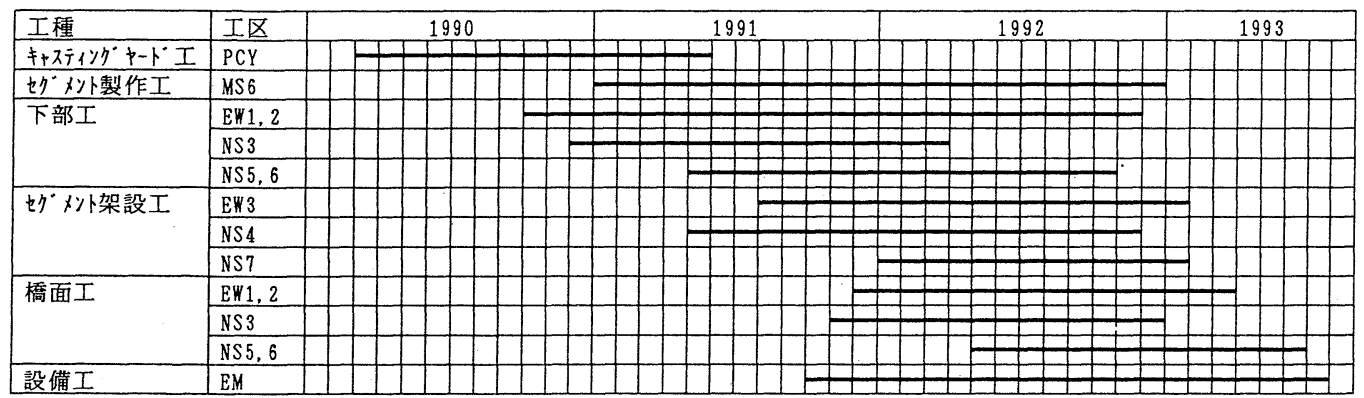

表一3 高架橋の概要（第 1 期工事区）

\begin{tabular}{|c|c|}
\hline 項 & 概 \\
\hline 延長 & 本線約 $19 \mathrm{~km}$ (片側3車線、上下線計 6 車線) \\
\hline 有効幅員 & $13 \mathrm{~m}$ (本線: 3 車線)、9.5m(出入路: 2 車線) \\
\hline 径間長 & $24.85 \sim 48.65 \mathrm{~m}$ \\
\hline 曲線半径 & $\mathrm{R}_{\mathrm{m} 1 \mathrm{a}}=280 \mathrm{~m}$ (本線)、 $90 \mathrm{~m}$ (出入路)、 $50 \mathrm{~m}\left(N-7^{\circ}\right)$ \\
\hline 勾配 & 繸断最大 $6 \%$ 、横断最大 $10 \%$ \\
\hline 構造形式 & 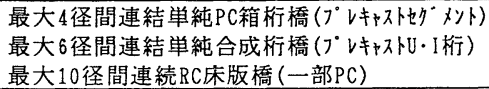 \\
\hline
\end{tabular}

表一4 プレキャストセグメントの諸元

\begin{tabular}{|c|c|c|c|c|c|c|}
\hline \multicolumn{2}{|c|}{ 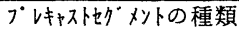 } & 長さ & 幅 & 高さ & 重量 & 備 考 \\
\hline D2 & \multirow{2}{*}{ 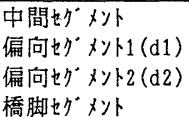 } & \multirow[t]{2}{*}{$\begin{array}{l}3.3 \sim \\
3.5\end{array}$} & $\begin{array}{r}6.7 \sim \\
12.2\end{array}$ & \multirow[t]{2}{*}{ 2. 4} & $\begin{array}{l}40 \sim \\
50\end{array}$ & $\begin{array}{l}\text { 主に } \\
2 \text { 車線用 }\end{array}$ \\
\hline D3 & & & $\begin{array}{l}10.0 \sim \\
15.6\end{array}$ & & $\begin{array}{l}50 \sim \\
65\end{array}$ & $\begin{array}{l}\text { 主に } \\
3 \text { 車線用 }\end{array}$ \\
\hline
\end{tabular}

表一5 主桁タイプと構成

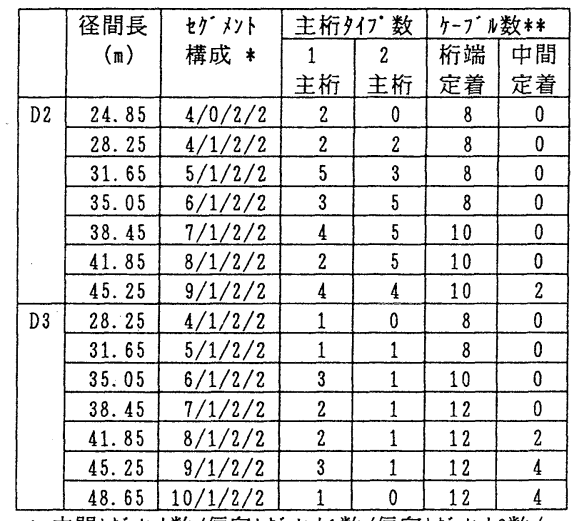

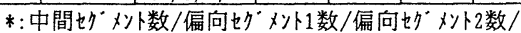

橋脚也グメン数

$* *: 5 \sim 19 K 15$

トセグメント部分の構造概要を表一 4,5 および図一2，3 に示す.

\section{3. 単純化・標準化}

\section{(1) 計画・設計}

\section{a）プレキャストセグメントエ法の採用}

本高速道路の高架橋部分の標準構造は, 原設計ではプ レキャストI桁によるPC 合成桁であったが, 以下のよ うな条件に基づく再検討を必要とした。

(1) 本工事は BOT (Build, Operate \& Transfer) 方式 による民活プロジェクトの一環であり，早期資金回収 のために完成が急がれた (急速施工の要求).

(2) プロジェクトの主体である民間事業会社は 30 年間 のメンテナンス義務を有するため, 規模の大きさに関 わらず品質確保が容易な構造物が要求された（単純 化・標準化の要求).

(3) 都市内高速道路のため, 施工時の地上部之の相互影 響が少ない工法が要求された。 

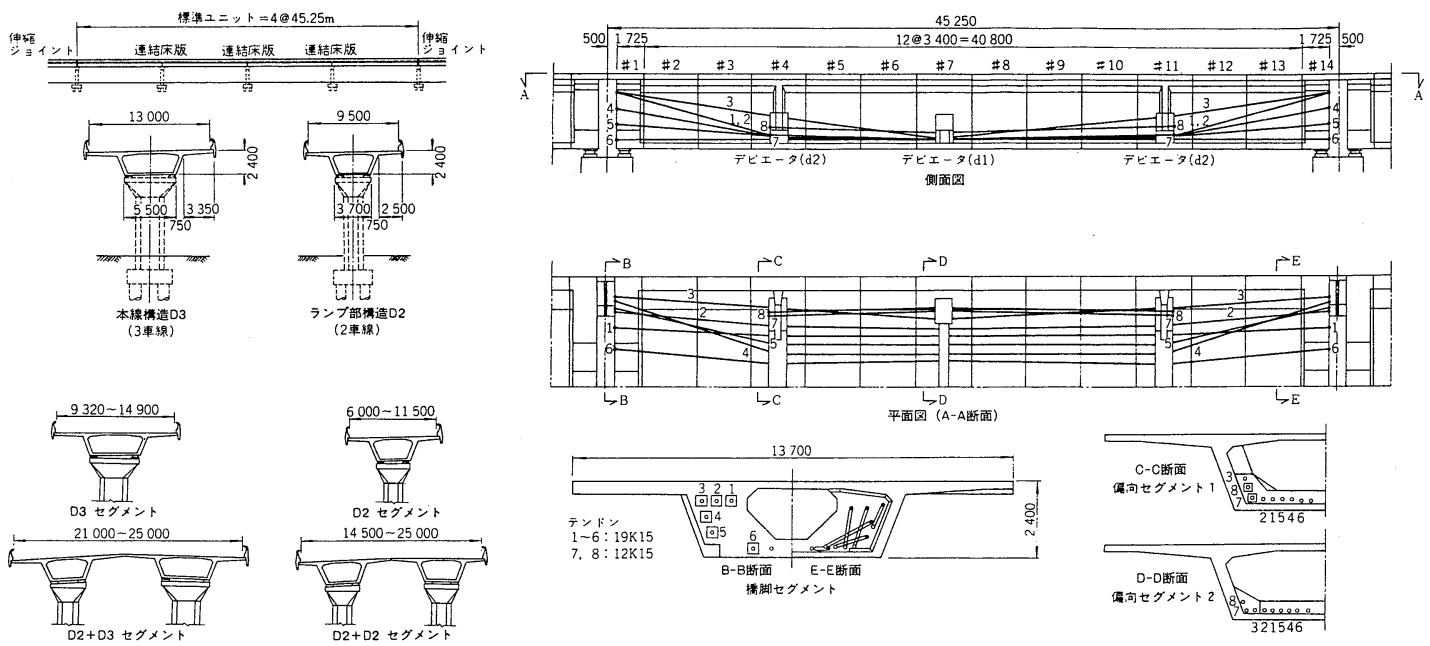

図一2 高架橋一般図

（プレキャストセグメント工法）
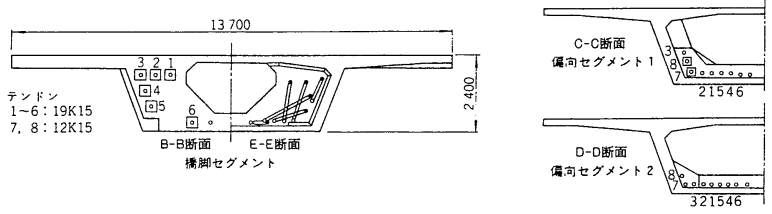

(4) 多くの道路, 鉄道線路, 運河, 埋設物などを横断す るため，ある程度径間長を長く取ることのできる構造 が要求された.

(5) 対象の規模が大きいものであったため, 設計・施工 を容易にする構造であることが望まれた（単純化・標 準化の要求).

(6) 都市内高速道路のため, 景観性が要求された.

(7) (1)，(5)および(6)より，構造の連続性が望まれた（標 準化の要求).

以上の条件の総合評価の結果, プレキャストセグメン ト, 外ケーブル, ドライジョイントといった基本構造が, 架設工法（スパンバイスパン工法）あ含んだ一つのパッ ケージとして採用された。

\section{b）構造詳細}

主桁は表一4，5 に示すように基本 2 タイプ（D2，D3） のセグメントからなり, 径間長抢よび道路幅の変化に対 して，これらを適宜組み合わせることで対処できるよ う，両タイプのセグメントの高さをそろえた。

外ヶーブル, ドライジョイントおよび単純桁などの単 純な構造の採用は, 施工段階に生じる品質あるいは工程 上の不確実性を設計段階である程度排除することに貢献 している。すすなわち，

・外ケーブル：PC 鋼材配置, 緊張作業およびグラウ 卜作業の信頼性向上

・ドライジョイント：エポキシ樹脂の品質管理が不要 ; 天候に左右されない

・単純桁：セグメント製作誤差, 桁架設誤差を 1 径間 で吸収できる；場所打ちコンクリートによ る閉合継目が不要

但し，これらの構造の採用はシステムのて長性を下

図一3 セグメントおよびケーブルの配置例（D3）

げ, 脆性的な破壊形態につながるため, 安全率を大きく 取ることで安全性の向上を図った。

セグメント製作作業の便宜を考え，ケーブル定着位 置・偏向位置の標準化を行い, 桁の幅・長さの変化に伴 うプレストレス量の調整は $\mathrm{PC}$ 鋼より線本数の調整のみ で行った. また, 各セグメントへの作用せん断力はその 架設後の位置によって異なるが，ここでは橋脚セグメン トを除く殆どのセグメントのウェブ厚およびウェブ内配 筋を同一とした。

したがって, 各析を個別に見れば，最適設計とはなっ ていないが，設計・施工の手間を加えたトータルメリッ トは得ることができた.

デビェータのケーブル通過部の製作には標準化した ディアボロ型枠2)を用い, 桁長・桁曲線の変化に起因す るケーブル角度の変化を吸収することができるようにし た。これにより, デビェータ中の埋め込みシースの位 置・形状のチェック作業の削除, 型枠の開口位置の固定 といった直接的効果に加え, 型枠の設置ミスの低減とい う間接的効果も得ることができた。

桁端部の橋脚セグメントは, 伸縮継手用・連結床版用 の 2 タイプがあり, 前者は架設終了時にそのまま伸縮継 手の設置が可能となるよう設計した。一方, 後者は, 現 場打ち連結床版コンクリート用の空きスペース $1 \mathrm{~m}$ を利 用して, セグメント製作誤差および桁架設誤差の吸収を 可能にした.

各主桁タイプごとの径間数を表一6に示す（ここに，2 主桁タイプ 1 径間は，架設トラスの作業の観点から， 2 径間と数えている). 出入路およびインターチェンジで の加速・減速用車線（計 38 ヶ所）による道路幅変化に対 応するため, 2 主桁夕イプが全体の約 $30 \%$ を占める結果 
表一6 主桁タイプと径間数

\begin{tabular}{|c|c|c|c|c|c|c|c|c|c|}
\hline \multirow{2}{*}{ 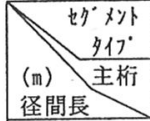 } & \multicolumn{3}{|c|}{ D 2} & \multicolumn{3}{|c|}{ D 3} & \multicolumn{3}{|c|}{$\mathrm{D} 2+\mathrm{D} 3$} \\
\hline & 1主行 & 2主桁 & 計 & 1主桁 & 2主桁 & 計 & 1主行 & 2主析 & 計 \\
\hline 24.85 & 4 & 0 & 4 & 0 & 0 & 0 & 4 & 0 & $4 \quad(0.4 \%)$ \\
\hline 28.25 & 15 & 5 & 20 & 3 & 0 & 3 & 18 & 5 & $23 \quad(2.0 \%)$ \\
\hline 31.65 & 22 & 12 & 34 & 11 & 1 & 12 & 33 & 13 & $46 \quad(4.1 \%)$ \\
\hline 35.05 & 40 & 22 & 62 & 29 & 0 & 29 & 69 & 22 & $91 \quad(8.0 \%)$ \\
\hline 38.45 & 65 & 113 & 178 & 52 & 9 & 61 & 117 & 122 & $239(21.1 \%)$ \\
\hline 41.85 & 93 & 79 & 172 & 113 & 8 & 121 & 206 & 87 & $293(25.9 \%)$ \\
\hline 45.25 & 190 & 83 & 273 & 152 & 8 & 160 & 342 & 91 & $433 \quad(38.3 \%)$ \\
\hline 48.65 & 0 & 0 & 0 & 2 & 0 & 2 & 2 & 0 & $2 \quad(0.2 \%)$ \\
\hline 計 & $\begin{array}{c}429 \\
(37.9 \%)\end{array}$ & $\begin{array}{c}314 \\
(27.8 \%) \\
\end{array}$ & $\begin{array}{c}743 \\
(65.7 \%) \\
\end{array}$ & $\begin{array}{c}362 \\
(32.0 \%)\end{array}$ & $\begin{array}{c}26 \\
(2.3 \%) \\
\end{array}$ & $\begin{array}{c}388 \\
(34.3 \%)\end{array}$ & $\begin{array}{c}791 \\
(69.9 \%)\end{array}$ & $\begin{array}{c}340 \\
(30.1 \%)\end{array}$ & 1131 (100\%) \\
\hline
\end{tabular}

となった。これにより 1 主桁 $/ 2$ 主桁遷移部の出現頻度 は無視し得ないものとなり, その部分の上下部工の設計 を標準化するインセンティブとなった.

c) 桁配置

各径間長ごとに径間数を整理したものを表一 6 に示 す. 都市内高架橋のため, 道路, 鉄道線路, 埋設物等の 障害物が多数存在していたが, 約 40\%（1131 径間中 433 径間）が標準径間長である $45.25 \mathrm{~m}$ を有している.

曲線半径が小さい場合, セグメント製作上（隣接セグ メント間の角度が大きいことからくる型枠セットの煩わ しさ）あるいは美観上（架設後のウェブ面の不連続性） の理由から, 本工事でのように $3.4 \mathrm{~m}$ と長いセグメント を用いることはまれである.ささらに, 架設トラスの操作 上の理由によりスパンバイスパン工法が用いられること ああまり行われない. 本工事では曲線半径が $90 \mathrm{~m}$ 程度 の箇所が数ヶ所含まれていたが，その前後の区間との施 工の連続性を保つためにプレキャストセグメント・スパ ンバイスパン工法を採用した。実際には，製作・架設・ 完成後 (写真一2) のいずれにおいても問題は生じなかっ た.

\section{（2）セグメント製作}

数量が多くかつ変化に富んだ道路線形を持つ高架橋に 柔軟に対応するためショートライン・マッチキャスティ ング方式を採用した（写真一 3 ）。 セグメントの設計自体 が既に標準化されていたため, 型染の標準化む容易であ り，4タイプに止めることができた（表一7）. 用意された 型枠数は最終的には計 50 組となった.

本工事で実際に発行された施工図の構成を表一8に示 す、種々の指標と比較した平均図面発行枚数は以下のよ うになる。

\section{・0.7枚/セグメント \\ $\cdot 8.6$ 枚/径間}

設計のかなりの部分を標準化していたにも関わらず, このように大量の図面を必要とした理由は, 線形管理が セグメント製作のキーポイントであるとの認識に基づ

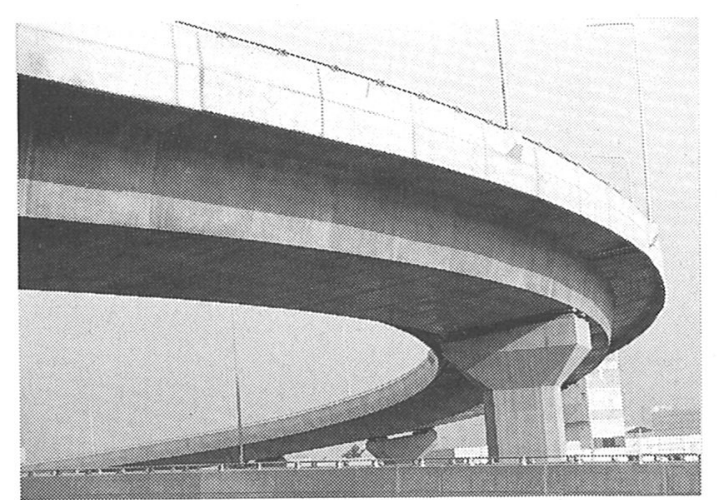

写真一2 急曲線部 (曲線半径 $90 \mathrm{~m}$ )

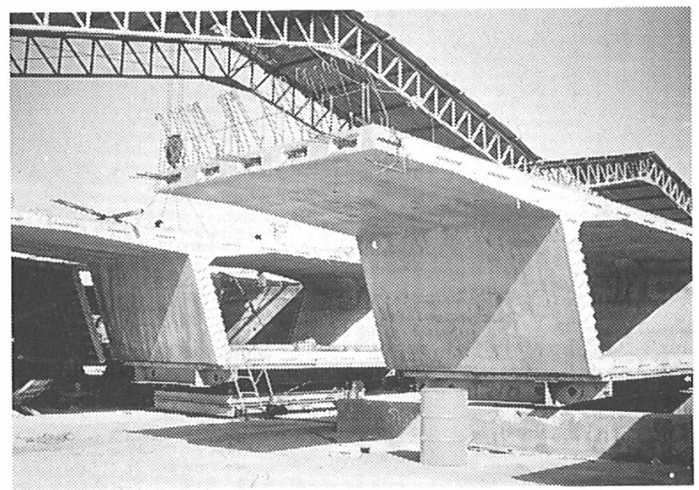

写真一3 ショートラインマッチキャスティング工法

表一7 セグメント型枠数

\begin{tabular}{|l|r|r|r|}
\hline 型枠タイプ & D2 & D3 & 計 \\
\hline 中間・偏向セグメッ用 & 21 & 14 & 35 \\
\hline 橋脚セグメト用 & 9 & 6 & 15 \\
\hline \hline 計 & 30 & 20 & 50 \\
\hline
\end{tabular}

表一8 施工図発行枚数

\begin{tabular}{|c|c|c|c|c|c|}
\hline 図面種別 & $\begin{array}{r}\text { 初期発行 } \\
\text { 枚数 }\end{array}$ & $\begin{array}{l}\text { 再発行 } \\
\text { 枚数 }\end{array}$ & 計 & 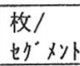 & \begin{tabular}{|l|} 
枚/ \\
径間
\end{tabular} \\
\hline 析配置図 & 1134 & 481 & 1615 & 0.11 & 1.43 \\
\hline 析種別詳細図 & 5055 & 2877 & 7932 & 0.54 & 7.01 \\
\hline 標準詳細図 & 55 & 135 & 190 & 0.01 & 0.17 \\
\hline 補修工用図面 & 4 & 8 & 12 & 0.001 & 0.01 \\
\hline 計 & 6248 & 3501 & 9749 & 0.67 & 8.61 \\
\hline
\end{tabular}

注：載荷試験用桁(1径間, 14 七少 メット)に対する施工図含む 


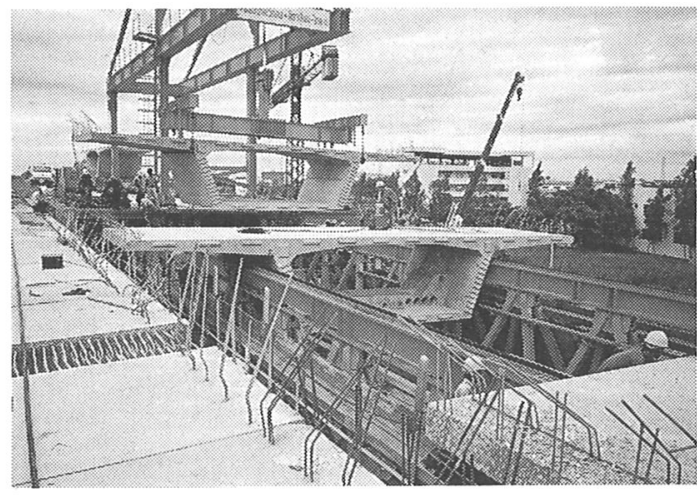

写真一4 スパンパイスパン工法（サポートタイプトラス）

表一9 高架橋路線上の主な障害物

\begin{tabular}{|c|c|}
\hline 障害物の種類 & 障害物直上の桁数（径間） \\
\hline 一般道路 & 45 \\
\hline 高速道路 & 4 \\
\hline $\begin{array}{l}\text { 架設済みの桁 } \\
\text { (インター } \\
\text { (インジ交差部) }\end{array}$ & 10 \\
\hline 鉄道 & 4 \\
\hline 沼 & 159 \\
\hline 運河 & 15 \\
\hline 計 & $237(21.0 \% *)$ \\
\hline
\end{tabular}

* : 径間総数1131に対する割合

き,左右の違いのようなわずかな差異も図面化したこと； 製作現場での使用の便を考え, 大縮尺の図面としたこと； わずかな設計変更も図面再発行の対象としたが，それが 非常に頻繁であったこと，などである。

すなわち，情報のあいまいさに起因するヒューマンェ ラーを，人的能力に依ってではなく機械的に防止しよう としたことが図面枚数の増加につながったと言うことが でき，今後の類似工事では人間工学的な点から再検討の 余地がある分野であろう.

\section{(3) 架 設}

本工事では，スパンバイスパン工法（写真一4）を単純 桁，外ヶーブル抢よびドライジョイントと組み合わせる ことで, 架設作業のクリティカルな部分から、コンク リート打設やエポキシ樹脂塗布など現場での管理に手間 のかかる作業の排除が可能となり, 架設作業は，単純な 組立作業となった。 また, 架設直後の橋面がそのまま次 径間の桁の架設用アクセスとして使え, 地上部の状況に 左右されず，同一の段取りで連続して架設作業を進める ことができたことも大きなメリットであった，工事区域 内の主な地上障害物とその直上に位置する桁の径間数を 表一9に示すが，架設工程はこれら障害物の影響をほと んご受けていない.
表一10 キャスティングヤードで使用した主なブラント

\begin{tabular}{|c|c|c|}
\hline 種 類 & 数量 & 力 \\
\hline ペチチリグプラット & 2 & 各 $60 \mathrm{~m}^{3} / \mathrm{hr}$ \\
\hline 乡价式がントリークレーシ & 5 & 80 t吊り \\
\hline $3 \eta-\eta v-\%$ & 4 & 10t吊り \\
\hline $\left.1^{\circ} \times 1 \times 1 A^{\circ}\right\rangle$ & 6 & $3 m^{3} / m i n$ \\
\hline トラォクミキ井 & 10 & $6 \mathrm{~m}^{3}$ 積み \\
\hline
\end{tabular}

表一11 架設トラスの概要

\begin{tabular}{|c|c|c|c|c|}
\hline トラスタイイ゚ & $\begin{array}{r}\text { 長さ } \\
\text { (m) }\end{array}$ & $\begin{array}{l}\text { 幅 } \\
\text { (m) }\end{array}$ & $\begin{array}{l}\text { 重量 } \\
(\mathrm{t})\end{array}$ & 基 数 \\
\hline サボート多侣トラス & 96 & $2.15 \times 2$ & 320 & NS4:2, NS7:2 \\
\hline ヘカガータイプトラス & 85 & 8.0 & 290 & EW $3: 6$ \\
\hline
\end{tabular}

\section{4. 機械化}

\section{（1）セグメント製作}

ヤード内に配置された主なプラントを表一10 に示す。 定常的に運営を行っている工場と比べると, プラントの 配置・使用上のある程度の非効率性は否めず，今後のプ ロジェクトではより自動化・機械化を進めるための改善 対象となる領域であると考えられる。

\section{（2）架 設}

使用した架設トラスの概要を表一11 に示す. 架設作業 開始に先立って, 全トラスが架設作業中に被る最大荷重 の $25 \%$ 増しの荷重による載荷試験を行い, 耐力および変 形性状の確認を行った，約 $1000 t$ の（等分布）荷重載荷 は，第一径間のセグメント（600-800t）上にコンクリー トブロックを追加載荷することで行った.

支持すべき荷重の大きさ, 使用回数の多さ, 施工速度 の速さ，事故が起きた場合の影響の大きさ，特に，既存 の道路上での架設作業があることなどを考慮すると， ス パンバイスパン工法で用いられる架設トラスではこのよ うな直接確認は不可欠であろうと考えられる。

\section{5. 集中化・一貫化}

\section{（1）組 織}

本工事は，企画，設計，入札，施工の各段階を一貫し て単一のプロジェクトマネージャ一組織が実施・管理・ 監督を行った（図一4）。これにより，企画・設計段階で は施工への事前の配慮, さらに施工段階では設計理念に 立ち戻った迅速・柔軟な判断, 各工区を見通した視野の 広い判断, あるいは全工区レベルでの情報のフィード バックを行うことが可能となった。

プロジェクトマネージャーはまた一部資材の購入計画 立案掞よび調達を行った。これにより，鉄筋，PC 鋼材他 の主要材料の安定供給および品質管理を図っただけでな く，ゴム支承，伸縮継手および防音壁などの製品につい 


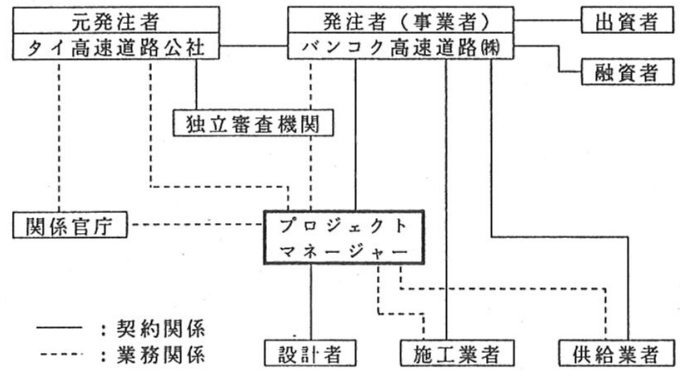

図一4 プロジェクト組織図

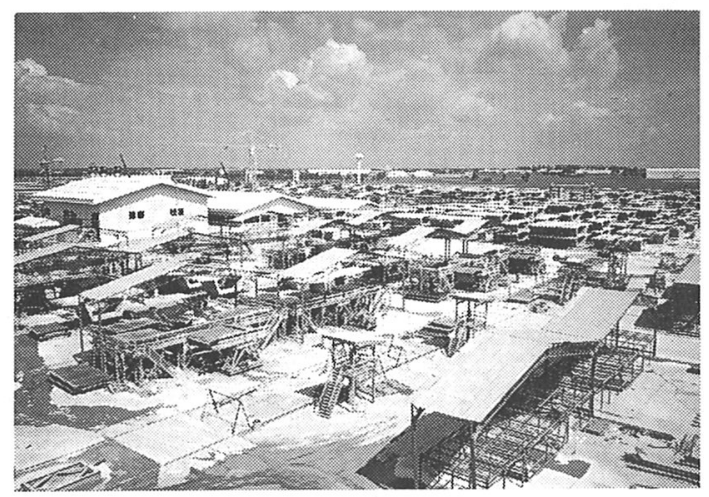

写真一 5 キャスティングヤード

ては, 高架橋全線にわたってそれぞれ供給元を一元化, 外観の統一を図ると共に，供給・設置工程および品質の 管理を容易にした。

\section{（2）セグメント製作}

セグメントの製作は 1 個所のキャスティングヤードに て集中的に行い, 品質の確保およびプラントの有効利用 を図った。 キャスティングヤードの光景を写真一 5 に示 す. バンコク市中心部から北に約 $60 \mathrm{~km}$ 離れたバンパイ ン地区に確保されたヤード敷地は, 約 20 万 $\mathrm{m}^{2}$ の広さを 持ち, 内部は共通ゾーン (事務所, 鉄筋加工場, シース 加工場他), 製作ゾーン (4 ゾーン) および仮置ゾーン (3 ゾーン）に分割されている3

ヤード総面積を他の諸量で除することにより求めた単 位ヤード面積は，それぞれ以下のようになる.

・約 $20000 \mathrm{~m}^{2} /$ トラス

・約 $4000 \mathrm{~m}^{2} /$ 型枠

・約 $14 \mathrm{~m}^{2} /$ セグメント

ショートライン・マッチキャスティング工法の採用に あかかわらず非常に広い面積となっている，その理由と して次のようなものが挙げられる。

(1) ヤード内にバッチングプラント，鉄筋加工場，シー ス加工場, 機械修理工場などを完備し, 原材料の搬入 さえあればセグメント製作が可能な体制を取った。
(2) 架設速度が非常に速く，セグメントの仮置数を多く することで架設作業に支障の無いようにする必要が あったため，仮置場面積が広くなった。

(3) 製作作業とセグメント運搬用車両の仮置場への乗入 れとの錯綜を防ぐために, ヤード内道路を広く取っ た.

(4) 多数の人員 (最盛期には 2 シフト合計約 1800 人)を 抱え, そのための事務所, 控え室, 食堂他の施設を必 要とした。なお，この中には, 生コン製造, 鉄筋・シー ス加工からセグメント搬出に至る全作業に必要なエン ジニア, 測量係, 検查係, オペレー夕, 労務者, 事務 員他が含まれている.

(5) 面積の拡大に伴い，ヤード内配置およびプラントの 動線が二次元的になり, アクセス関係の面積がさらに 上乗せされる形となった。

このように本工事では, 残念ながら単位面積の点での スケールメリットを得ることはできなかったと言える. これに比して，通常の工事では規模が余り大きくないた め, 型枠数が少ない, 要求されるセグメント仮置数が少 ない(種々の不確定性が低い, かつ架設速度が遅いため： 6. (1) 参照), 材料加工機能を抱え込まない, ヤード内 配置が一次元的であるなどの理由により, 単位面積は上 記の数字よりかなり減少するあのと考えられる。

\section{（3）実物大載荷試験 5 -7)}

本工事の規模の大きさは，試験用桁の製作およびそれ を用いての実物大載荷試験を行うことに対する十分な理 由付けとなった。試験の企画・実施・結果の評価は, プ ロジェクトマネージャーによる運営下に置かれ, 得られ た情報は多方面で利用された。

試験は架設開始前および終了後の二度に分けて行われ た，施工開始前の試験は非破壊試験であり，スタッフの 訓練, プラントの機能確認, 施工マニュアルの整備, 設 計の改善, 設計荷重下での挙動確認などが行われた。一 方, 架設終了後の載荷試験は桁が実際に破壊に至るまで 続行する破壊試験であり, 実際の耐力のチェックにより 架設済みの桁の直接的な安全性確認を行うことができ た.

\section{6. 急速施工}

\section{（1） セグメント製作}

各タイプのセグメントの標準サイクルタイムを表一12 に示す．但し，ショートライン・マッチキャスティン グ工法をタイ国で実施するのは初めてであったため,こ の製作速度を達成するまでに 7 8 ヶ月の習熟期間を要 した。習熟後の製作速度は，平均 900 個 /月（最高 1011 個／月）に達した（図一5）。 
表一12 セグメント製作の標準サイクルタイム

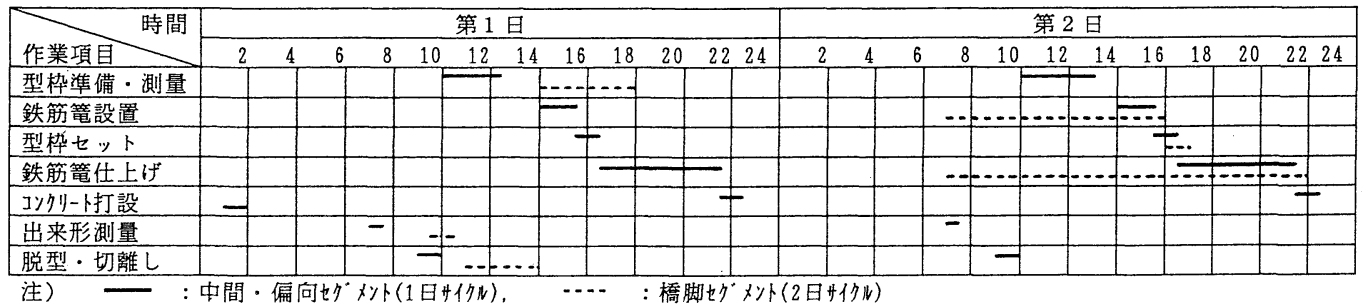

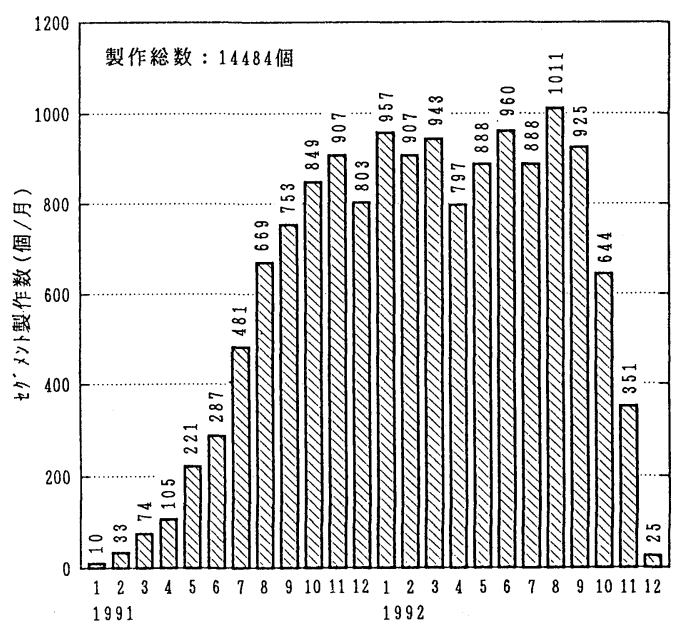

図一 5 セグメント製作工程

図一6 は， 1 径間分のセグメントを全て製作し終わる までに要した時間を整理したもので ある．単位時間当 たりのセグメントの製作総数自体は標準サイクルタイム から予想されるあのとほぼ同じであるにもかかわらず, 1 径間分のセグメントの製作時間は予想値（10２0日） よりあかなり大きくなる傾向があった。この理由として は, セグメント再製作，型枠の不具合，休日等による影 響屯あるが，より大きな要因として，その時々の局面で の必要型枠タイプと実際に空いている型枠の不一致，お よび複数の架設現場での工程の変更に伴う製作工程の途 中変更が挙げられる，通常の工事では架設工程が比較的 単純であるため， 1 径間分のセグメントの製作時間は， 平均值，バラッキ共に減少するあの之考えられる.

セグメントの製作速度の妥当性は単独で評価されるべ きものではなく, 架設作業速度との調和を考慮して評価 されるべきである，本工事では，前段で述べた問題に加 え，1セグメントごと・1 径間ごとに製作するという マッチキャスト工法の特性からくる制約, セグメントコ ンクリートの必要養生期間に起因する製作之架設間の夕 イムラグ等の影響により, 製作工程は不確定性の高いも のとなった．これは架設速度の速さとも相まって，セグ メント仮置個数の増大の形で現れる結果となった，図一

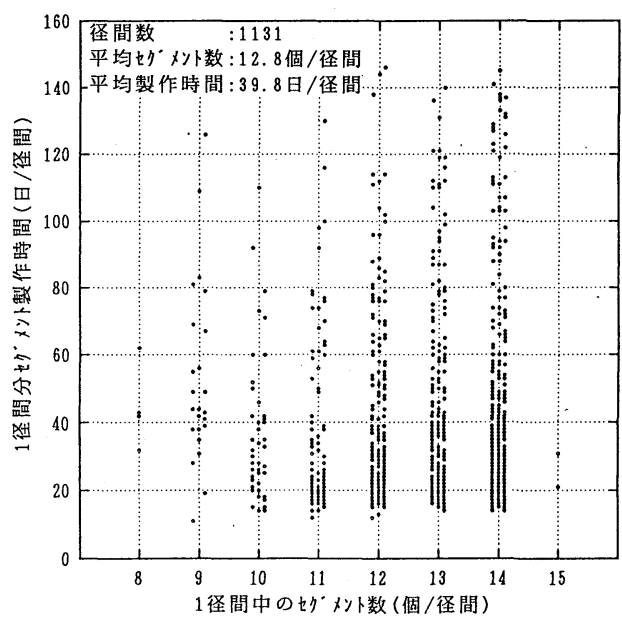

図一6 セグメント製作時間 (1 径間分)

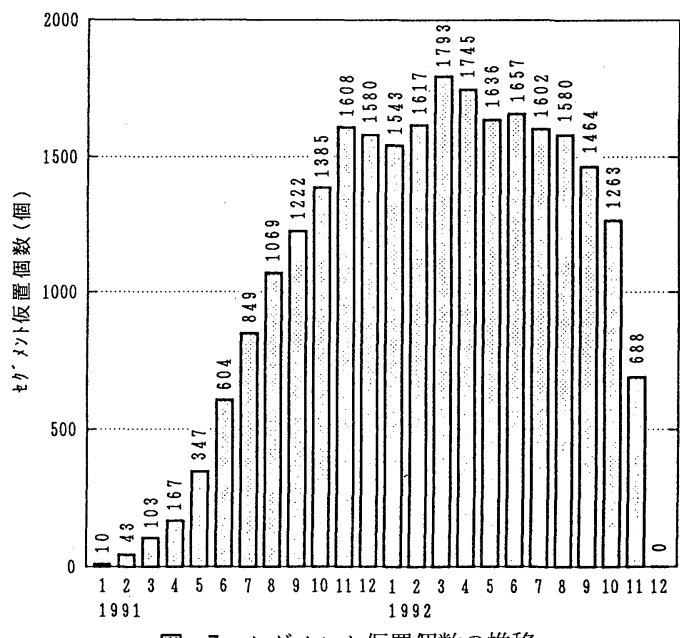

図一7 セグメント仮置個数の推移

7 に仮置個数の推移を示す.

\section{（2）架 設}

架設作業の標準サイクルタイムを表一13に示す. 実際 には，以下に示すような状況が頻繁に発生したため，長 期間連続して標準サイクルタイム通りに作業が進行する ことは少なかった。

・サポートタイプ：1主桁 $/ 2$ 主桁遷移部での段取り 
表一-13 架設作業サイクルタイム

\begin{tabular}{|l|l|l|l|l|l|l|l|l|l|l|l|l|l|l|l|l|l|l|l|l|l|l|}
\hline \multirow{2}{*}{ 作業項目 } \\
\hline
\end{tabular}

注 1) 本表はサポートタイプトラスで2 日サイクルの場合。1日サイクルの場合は、夜間休止無し。

注 2 ）ハンガータイプトラスの場合、トラスの移動・架設共に約 5 割増しの時間を要し、標準サイクルタイムは 3 日となる。

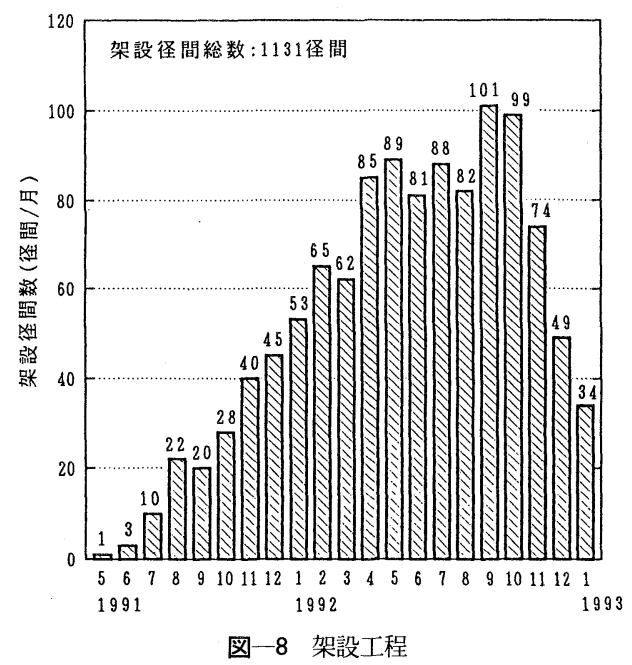

替え，発進部でのトラス長調整

・ハンガータイプ：トラス長の調整，曲線部での横移 動

・両タイプ共通 : トラスの分解・移動・再組立，セ グメント製作待ち

全トラスが稼働していた最盛期には，平均 90 径間／ 月（最高 101 径間 /月，平均径間長 $41 \mathrm{~m}$ ) の架設速度を 達成することができた（図一8)。習熟期間はいずれのト ラスにおいても，3一4ヶ月程度であった。

架設時のセグメントコンクリートの材令分布を図一9 に示す．当初計画では架設時のコンクリート材令は 28 日としたが，実際にはセグメント製作工程と架設工程の 不一致のため, 材令が 28 日未満のセグメントの架設も 相当数行った.

\section{7. 品質（問題の発生）}

\section{（1）セグメント製作}

各タイプの型枠の平均使用回数は表一14 に示す通り

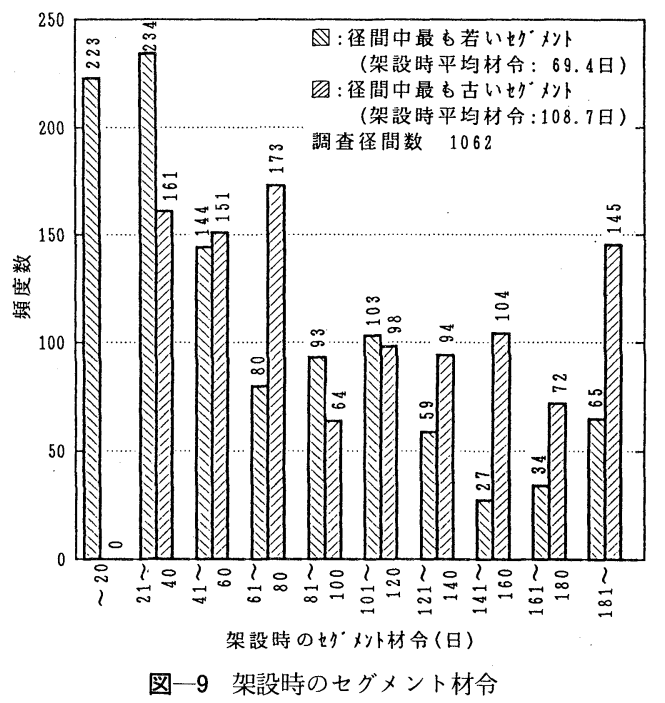

である．マッチキャスト用定置式鋼製型枠の使用可能回 数は, 一説には打打よそ 1000 回之言われているが, 所定 のセグメント製作精度を確保していくためには，使用期 間中の頻繁なメンテナンスが必要である。本工事では最 低月 1 回の型枠の定期検査を行ったが，その結果，表一 15 に示す通りかなりの頻度で補修が必要となった。な お，これらの型枠は第二期工事区においても引き続き使 用するため, 使用回数は最終的には表一14 中に示されて いる数字の約 2 倍程度になる予定である.

セグメントの許容製作誤差を表一16 に示す.セグメン 卜単体の製作精度に関してはあまり問題は生じなかった が，各セグメントデー夕を集計して作成する桁全体の仕 上り線形に関しては誤差が大きくなる傾向があり，架設 用デー夕作成の段階で座標の修正を行う必要が約 70\% の桁で生じた（表一17）。修正は桁全体を最適位置まで 3 次元的に移動させることで行った．桁全体としての製作 誤差の発生は，セグメントの大きさ，平面線形，あるい は発生方向などとは特に相関関係が無いように見受けら れ，どのような場合でも等しく線形管理が必要であるこ 
表-14 型枠の使用回数

\begin{tabular}{|c|c|c|c|c|}
\hline \multicolumn{2}{|c|}{$七 \eta^{\circ} x \% ト 夕\left\{7^{\circ}\right.$} & セグxット数 & 型枠数 & 平均型枠使用回数 \\
\hline \multirow[t]{2}{*}{ D2 } & 中間·偏向 & 7954 & 21 & 379 \\
\hline & 橋脚 & 1488 & 9 & 165 \\
\hline \multirow[t]{2}{*}{ D3 } & 中間·偏向 & 4270 & 14 & 305 \\
\hline & 橋脚 & 776 & 6 & 129 \\
\hline & 計 & 14488 & 50 & 290 \\
\hline
\end{tabular}

注：再製作された枋メト（25個）は含まず

表一15 型枠のメンテナンス頻度

\begin{tabular}{|c|c|c|c|c|}
\hline 作業内容 & 型枠本体 & 油圧機器 & 計 & 平均犷回数 \\
\hline 調整 & 433 & 115 & 548 & 1.5 回/型枠・月 \\
\hline 修理 & 55 & 563 & 618 & 1.7 回/型枠・月 \\
\hline 交換 & 156 & 31 & 187 & 0.5 回/型枠・月 \\
\hline \hline 計 & 644 & 709 & 1353 & 3.7 回/型枠・月 \\
\hline
\end{tabular}

注: 本表は型伜46基の1991年11月〜1992年6月までの8ヶ月間 の記録を集計したすの。
表一16 許容誤差（セグメント製作）

\begin{tabular}{|c|c|}
\hline 項 & 許容誤差 \\
\hline 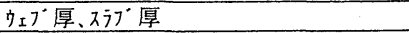 & $\pm 5 \mathrm{~mm}$ \\
\hline 也グメットの高さ & $\pm 5 \mathrm{~mm}$ \\
\hline セグメットの偪 & $\pm 20 \mathrm{~mm}$ \\
\hline 枋メットの長さ(セグメント1個) & $\pm 10 \mathrm{~mm}$ \\
\hline （連続する2個） & $\pm 15 \mathrm{~mm}$ \\
\hline (1径間分) & $\pm 25 \mathrm{~mm}$ \\
\hline 多价厸、デピーター寸法 & $\pm 10 \mathrm{~mm}$ \\
\hline 外ケープ用貫通孔位置 & $\pm 5 \mathrm{~mm}$ \\
\hline ジョ忟の目違い(上下·左右) & $\pm 5 \mathrm{~mm}$ \\
\hline 职メット中心線のずれ & $\pm 20 \mathrm{~mm}$ \\
\hline 連続するセグメント個の平面角度のずれ & $\pm 0.001 \mathrm{rad}$ \\
\hline 連続するセグメント2個の鈆直角度のずれ & $\pm 0.003 \mathrm{rad}$ \\
\hline
\end{tabular}

表一17 製作後に線形の修正を要した桁数 ${ }^{1)}$

\begin{tabular}{|c|c|c|c|c|c|c|c|c|c|c|c|c|}
\hline 妨 xット夕夕プ & \multicolumn{4}{|c|}{ D 2 桁（製作総数：743） } & \multicolumn{4}{|c|}{ D 3 桁（製作総数: 388$\left.)^{3}\right)$} & \multicolumn{4}{|c|}{ D 2 + D 3 (製作総数: 1131) ${ }^{4}$} \\
\hline 曲線半径尘方 & $\begin{array}{l}\text { 橋軸 } \\
\text { 方向 }\end{array}$ & $\begin{array}{l}\text { 橋軸直 } \\
\text { 角方向 }\end{array}$ & $\begin{array}{l}\text { 鈆直 } \\
\text { 方向 }\end{array}$ & 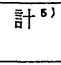 & $\begin{array}{l}\text { 橋軸 } \\
\text { 方问 }\end{array}$ & $\begin{array}{l}\text { 橋軸直 } \\
\text { 角方向 }\end{array}$ & $\begin{array}{l}\text { 鈶直 } \\
\text { 方向 }\end{array}$ & $\bar{z}^{5)}$ & $\begin{array}{l}\text { 橋軸 } \\
\text { 方向 }\end{array}$ & $\begin{array}{l}\text { 橋軸直 } \\
\text { 角方向 }\end{array}$ & $\begin{array}{l}\text { 鈶直 } \\
\text { 方向 }\end{array}$ & $\bar{t}^{5)}$ \\
\hline $\mathrm{R}=\infty$ (直線) & 137 & 136 & 125 & 274 & 17 & 35 & 40 & 56 & 154 & 171 & 165 & 330 \\
\hline $1000 \mathrm{~m} \leqq \mathrm{R}<\infty$ & 3.4 & 43 & 34 & 81 & 34 & 54 & 61 & 107 & 68 & 97 & 95 & 188 \\
\hline $\mathrm{R}<1000 \mathrm{~m}$ & 60 & 96 & 58 & 145 & 49 & 68 & 74 & 122 & 109 & 164 & 132 & 267 \\
\hline 合計 & 231 & 275 & 217 & 500 & 100 & 157 & 175 & 285 & 331 & 432 & 392 & $785^{41}$ \\
\hline
\end{tabular}

注 1)キャスティングヤードで製作誤差が発見されたすのに限る。

注 2) $500 / 743=67 \%, 500 / 785=64 \%, 743 / 1131=66 \% \quad$ 注 $3 ） 285 / 388=73 \%, 285 / 785=36 \%, 388 / 1131=34 \% \quad$ 注 4 ) $785 / 1131=69 \%$

注 5 ) 1 つの桁で 2 方向以上に修正を要したすのは、合計欄では 1 つとして数えている。

表一18 品質管理項目

とを示唆している.

セグメント製作の各過程に品質管理項目を設定し（表

-18), それぞれ所定の方法・基準に従って, 検査・確認 を行った. 検査結果例として, 脱型直後に発見されたセ グメントの損傷に関するデータをまとめたものを表一19 に示す. 損傷箇所は端面が他に比べて圧倒的に多く, 若 材令の多段せん段キーおよびガイドキーが脱型・切離し 作業に対し非常に敏感であることがわかる. せん段キー の健全度はドライジョイント方式では特に重要な事項で あるが, 本工事では, 設計時にせん段キ一の若干の損傷 は許容する余裕のある設計を行っていたため, 損傷の発 見が与える心理的圧力を軽減する効果があった。 なお， 表中の損傷の多くは, 構造上問題とはならない程度の軽 微なものであり, 桁の外観に影響を及ぼさない場合は補 修を要しないものであった. 例えば, 構造上問題があり, 補修を要すると判断されたジョイントの数は 97 個で あった. 表一20にキャスティングャードでの補修の対象 となったその他の不具合のリストを示す。

補修不可能な損傷・形状ミス等の理由で廃棄されたセ グメント数は 25 個 (全数の $0.17 \%$ ) であり,これらは再 製作の対象亡なった（表一21参照）. タイで初めての工 法である上に, 急速施工, セグメントの長距離運搬など, 事故・ミスの潜在的要因は多く, 計画時においては米国 での類似工事の統計值 ${ }^{8}$ から, 上記の 10 倍程度の棄却率

\begin{tabular}{|c|c|}
\hline チェック時期 & 項 \\
\hline 1.鉄筋篭吊込み前 & 鉄筋篭（治具上），型染，プレストレス定着具 \\
\hline 2. 内型枠七ッ卜前 & 下床版鉄筋，ウェプ鉄筋 \\
\hline 3.コックリート打設前 & 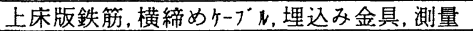 \\
\hline 4. コシクリート打設中 & 打設作業 \\
\hline 5. 脱型·切離し前 & 測量, コリクリート強度,横締め (仮緊張) \\
\hline 6.次プロック製作前 & マッチキャスト使用の可否，埋込み金具位置，損傷度 \\
\hline 7. 積出し前 & $\begin{array}{l}\text { 横締め(本緊張)，外ランド切断,グラウティング， } \\
\text { 補修，外観，コンクリート強度 }\end{array}$ \\
\hline 8. 積出し後 & 積出し作業,架設現場での補修 \\
\hline
\end{tabular}

表一19 セグメント製作時の損傷箇所（コンクリート部分）

\begin{tabular}{|c|c|c|}
\hline 部 所 名 & $\begin{array}{l}\text { 全体数 } \\
\text { (面) }\end{array}$ & $\begin{array}{c}\text { 損傷数 } \\
\text { (面) }\end{array}$ \\
\hline ウIプ端面 (妻枠側) & 15605 & $6911(44.3 \%)$ \\
\hline ウェブ端面（マッチキャトスト側） & 13343 & $4080(30.6 \%)$ \\
\hline 床版端面 (妻枠側) & 15605 & $7733(49.6 \%)$ \\
\hline 床版端面（マォチチャスト側） & 13343 & $5483(41.1 \%)$ \\
\hline ウェブ 側面 (内面) & 14474 & $1687(11.7 \%)$ \\
\hline ウェブ 側面 (外面) & 14474 & $424(2.9 \%)$ \\
\hline 下床版 (上面) & 14474 & $4(0.03 \%)$ \\
\hline 下床版 (下面) & 14474 & $280(1.9 \%)$ \\
\hline 上床版 (上面) & 14474 & $2(0.01 \%)$ \\
\hline 上床版 (下面) & 14474 & $14(0.1 \%)$ \\
\hline 上床版 (側面) & 14474 & $6(0.04 \%)$ \\
\hline $\bar{y}^{\prime} t^{\prime} I-y-$ & 3320 & $620(18.7 \%)$ \\
\hline 多仍フラ人（支点隔壁） & 2262 & $468(20.7 \%)$ \\
\hline
\end{tabular}

注 : 損傷の判定は非常に撖しい基準に基づいてお り、ごく軽微なあのも含まれている。 
表一20 セグメントの不具合（キャスティングヤードで発見さ れた主なあの)

\begin{tabular}{|c|c|}
\hline 不具合の内容 & 発生頻度 \\
\hline 寸法誤差 & 39 \\
\hline 左右の向き & 1 \\
\hline 変形 & 1 \\
\hline 部分的欠損 & 1 \\
\hline ひび割れ & 5 \\
\hline ジ方、豆板 & 2 \\
\hline 鉄筋のかぶり & 3 \\
\hline 鉄筋 & 8 \\
\hline 定着具 & 35 \\
\hline$P C$ 鋼材 & 22 \\
\hline ケープ通過部 & 1 \\
\hline 埋込み金具 & 41 \\
\hline 仕上げ & 3 \\
\hline 計 & 162 \\
\hline
\end{tabular}

表一21 セグメントの廃棄理由

\begin{tabular}{|c|c|}
\hline 廃棄理由 & 廃棄個数 \\
\hline 寸法誤差 & 2 \\
\hline ひび割れ & 2 \\
\hline コールドジ & 3 \\
\hline マッチキャスト面損傷 & 1 \\
\hline 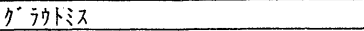 & 1 \\
\hline コンクリート強度 & 1 \\
\hline ヘッドリッグミスによる損傷(製作やード) & 4 \\
\hline (架設現場) & 3 \\
\hline 直前の設計変更 & 1 \\
\hline その他(手続きミスなど) & 7 \\
\hline 計 & 25 \\
\hline
\end{tabular}

を予想していたため, 得られた結果は満足すべきもので あったと言えよう。

一方，架設作業中に初めて発見された不具合例を表一 22 に示す。これらは廃棄の対象とはならなかったが, 架 設作業中又は後の補修を必要とした，ほとんどのあのは 製作中の検査で見過ごされたものであるが，本工事で採 用されたチェック体制では捕捉困難なすのあ幾つか含ま れている(例：セグメント仮置き中の変形).

\section{（2）架 設}

桁端部の橋軸直角方向および鉛直方向位置は，表一23 に示す許容誤差に従い，架設時に厳密に調整された．桁 端部の橋軸方向位置および杕中央部レベルに関しては特 に許容誤差は設けなかったが，セグメント製作時の誤差 管理でカバーし得ない部分，すなわち，セグメントの仮 置期間中の変形, 架設工程の変更により生じる架設後ク リープ変形量の見込み違い，および上越し計算自体の誤 差の累積効果により，かなりのバラッキを示した。しか し，支承回りの設計に予め余裕を持たせていたこともあ り，構造的にはほとんどのものが問題無く，高欄位置お よびアスファルト舗装厚の調整による対策等で十分で あった。

全てのダイアフラム（橋脚セグメント）およびデビ エータ（偏向セグメント）には，約 10\%までの追加プレ
表-22 セグメントの不具合

(架設作業中に発見された主なむの)

\begin{tabular}{|c|}
\hline 項 目 \\
\hline 寸法誤差 \\
\hline 左右の向き \\
\hline 変形 \\
\hline ひび割れ \\
\hline 定着具背面空洞 \\
\hline $\bar{T}^{\circ} t^{\circ} I-夕-$ \\
\hline 定着具 \\
\hline 埋込み金具 \\
\hline
\end{tabular}

表一23 桁の許容架設誤差

\begin{tabular}{|c|c|}
\hline 項 & 許容誤差 \\
\hline ジョイッの目違い(上下·左右) & $\pm 5 \mathrm{~mm}$ \\
\hline セグメット中心線のずれ & $\pm 20 \mathrm{~mm}$ \\
\hline 橋脚セグメント心線のずれ & $\pm 5 \mathrm{~mm}$ \\
\hline 橋脚セグメント中心線上のレベルのずれ & $\pm 5 \mathrm{~mm}$ \\
\hline 連続するセグメッ2個の平面角度のずれ & $\pm 0.001 \mathrm{rad}$ \\
\hline 連続するゃグメッ2個の平面角度のずれ & $\pm 0.003 \mathrm{rad}$ \\
\hline
\end{tabular}

表一24 架設作業中のセグメントの損傷理由

\begin{tabular}{|c|c|c|}
\hline 損傷箇所 & 損傷理由 & 損智個数 \\
\hline 上 $277^{\circ}$ 部分的欠損 & $\eta$ レー傮倒 & 1 \\
\hline 上スラフひび゙割れ & 仮支承の不具合 & 1 \\
\hline 上スラフ剥離 & 同上 & 1 \\
\hline 上スラフ 部分的欠損 & 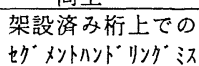 & 2 \\
\hline 上ス行部分的欠損 & 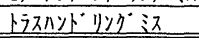 & 2 \\
\hline 計 & & 7 \\
\hline
\end{tabular}

ストレスを可能にする予備ケーブル設置用孔を補強と共 に設置した（D2 セグメント：1個/セット，D3 セグメ ント：2 個/セット).これらの予備孔の主目的は供用開 始後のプレストレス損失あるいは荷重増加に対するあの であったが, 実際には, 定着具の取付ミス, セグメント 製作後の設計変更, 緊張作業の不備などをカバーするた めに，6セット（全数の $0.04 \%$ ）の予備孔が既に施工中 に使用された。この予備ケーブル設置用孔の存在は, 発 注者, 設計者㧍よび施工者の全てに安心感を与える保険 として，必要な初期投資に比してその果たす役割は大き いものがある.

架設作業に起因するセグメントの損傷事例は 7 例（セ グメント全数の $0.05 \%)$ である. 損傷箇所・原因を表一 24 に示す。なお，幸いこれらはいずれす再製作の対象と はならず，原位置にて補修された。

\section{8. まとめ}

本プロジェクトの反省も兼ねて, 今後の類似工事の計 画に当たって重要と思われる事項を，以上のデータでは 表現しづらいものも含めて以下に簡単にまとめる.

（1）大規模施工，急速施工あるいは省力化施工の妥当 性の判断は, 評価方法（評価範囲, 評価基準, 統計処理 方法，コスト算出方法）次第であるため，できるだけ 
トータルメリットの観点から見ることが重要である.

また，これらのメリットを最大にするためには，基本 計画の段階でプロジェクト全体を事業として捉える, 工 事量 (工区) 設定の最適化を図る, PM（プロジェクトマ ネージメント)・CM (コンストラクションマネージメン ト）の導入などの舞台作りが必要であると考えられる.

（2）プレキャストセグメント橋の計画立案時には, 全 体と各要素および各要素間の関係, 具体的には設計・施 工の連続性, 製作と架設の調和, 上部工と下部工の関係 などに注意する必要がある. 施工規模 - 速度の増加に伴 いこの問題の重要性は増してくる.

（3）大規模かつ急速に製作・施工する際に得られるプ レキャストセグメントの品質は, 必ずしも満足なあので はない場合がある。したがって，作業中に問題の発生し づらい仕組み作り，および製品の許容度を上げ，製作・ 架設作業中の棄却率を減らすことのできる仕組み作りを 予めしておくことは, 工程・コストに関わる不確実性の 減少に寄与するむのと考えられる. 以下に, 本プロジェ クトでの適用例を示す.

・作業中に問題の発生しづらい仕組み作り：単純化, 標 準化, 繰り返し作業, マニュアル化, 外ヶーブル, ド ライジョイント

・製品の許容度を上げ，作業中の棄却率を減らすことの できる仕組み作り：予備ヶーブル設置用孔, 予備のせ ん断キー, 連結単純桁

文献 8)には, 米国カリフォルニア州におけるプレキャ ストセグメント橋のデータが広範囲にわたってまとめら れており, 同形式の橋梁に関心のあるあのにとって非常 に有益な情報を与えてくれる. 幸いバンコク第二高速道 路工事は, 単一工事で既に十分な量の情報量を有してお り，上記文献にならって情報の整理を行えば興味のある
結果が得られるのではないかと考えたことが本文執筆の 動機である. 実際に発生した問題についてもまとめてあ るので, 類似工事の計画時の一助になれば幸いである.

\section{参考文献}

1）白石暢明, 小倉好一, 竹林稔雄 : バンコク第 2 高速道路 (第一期工事) の施工, 橋梁之基礎, Vol. 27, No. 5, pp. 8 $-14,1993.5$.

2）白石暢明, 竹林稔雄, 谷沢次康 : バンコク第二高速道路の 計画および設計一外ヶーブル方式によるプレキャストブ ロック工法, プレストレストコンクリート, Vol. 34, No. 4, pp. 42-51, 1992.7.

3) Shiraishi, N., Race, D., Short, M. and Kitta, T.: Bangkok Second Stage Expressway-Construction of the Segmental Viaducts, FIP Symposium '93 Proceedings, pp. 1221-1228

4) Shiraishi, N. and Fox, P.D. : Bangkok Second Stage Expressway - Viaduct Design Overview, FIP Symposium '93 Proceedings, pp. 1123-1130.

5) Takebayashi, T., Deeprasertwong, K., Honda, B. T., Umeki, H.and Kumasaka, T.: Full Scale Testing of a Precast Concrete Bridge with External Tendons and Dry joints, FIP Symposium '93 Proceedings, pp. 11451152 .

6) Takebayashi, T., Deeprasertwong, K. and Leung, Y. W.: A Full Scale Destructive Test of a Precast Segmental Box Girder Bridge with Dry Joints and External Tendons, Proc. Instn. Civ. Engrs Structs \& Bldgs, 104, 297-315. Aug., 1994.

7）竹林稔雄, K. Deeprasertwong, Y. W. Leung: ドライ ジョイント・外ケーブル方式のプレキャストセグメント桁 の実物大破壊試験, プレストレストコンクリート, Vol. 36, No. 5, pp. 41-53, 1994.9 .

8) Moreton, A. J. : Special Report Segmental Bridge Construction in Florida - A Review and Perspective, PCI Journal, 1989.6.

(1994.7.1 受付)

\title{
VARIOUS MEASURES TAKEN AND QUALITY ACHIEVED IN PRECAST SEGMENTAL BRIDGE CONSTRUCTION
}

\author{
Nobuaki SHIRAISHI and Toshio TAKEBAYASHI
}

\begin{abstract}
Precast segmental bridges with external tendons and dry joints were employed together with the span by span erection method as the standard structural form for the viaducts in the Bangkok Second Stage Expressway, which contributed in the realization of a megascale rapid construction. This paper, presenting various data, describes the outline of the measures taken in the project such as simplification, standardization etc. and the construction programs and the quality actually achieved.
\end{abstract}

